\title{
The Role Of Social Skills on Social Support Mediated by Quality of Friendship in Special Need Children at Inclusive Primary School
}

\author{
Cut Mellyza Rizka ${ }^{1}$, Farida Kurniawati ${ }^{2}$ \\ \{cutmellyza@gmail.com ${ }^{1}$, farida1@ui.ac.id ${ }^{2\}}$ \\ Department of Psychology, University of Indonesia, \\ Depok, Indonesia
}

\begin{abstract}
This study investigates the influence of social skills on social support mediated by the quality of friendship in special needs children. Methods: This study used a quantitative research design. The instruments used were the Social Skill Improvement System (Gresham \& Elliott, 2008) for measuring social skills; the Social Support Questionnaire for Children (Harter, 1985) for measuring social support; and the Friendship Quality Questionnaire (Parker \& Asher, 1993) for measuring the quality of friendship. A total of 292 participants over the age of 10 years old, who were enrolled in inclusive elementary schools spread throughout the Province of DKI Jakarta, were included in the research. A multiple regression analysis was conducted. Results: Results demonstrated that the quality of friendship fully mediates the development of social skills and social support offered to special needs children. All variables had significant relationships and influence in this research $(p<0.05)$. Conclusion: These results indicate the importance of creating small study groups to support academic success, and small play groups to support non-academic success, which improves social support, social skills, and friendship quality in special needs children studying at inclusive primary schools.
\end{abstract}

Keywords: Social skills, social support, friendship quality, special need children, inclusive primary school.

\section{INTRODUCTION}

Every child has the same right to obtain an education in their own country, including special needs children. Special needs children are children that have limitations in physical and cognitive abilities, which affect their application to social functioning [1]. Many kinds of education services are available in every country for special needs children. One of them is the inclusive school [2]. An inclusive school is a school that accommodates all kinds of students' needs without exception. This school places regular students and special needs children in the same school environment. The main purpose of the inclusive school is to develop the potency and capability of special needs children in social terms [3].

Special needs children in an inclusive school have an opportunity to develop their social skills through inclusive socialization with their peers. Special needs children can enhance their cooperative skills, build respect, help each other, and become a supportive asset in wider society [3]. Thus, it can be concluded that an inclusive school provides the same opportunities 
for special needs children to develop their social skills as regular children. However, the different social conditions facing special needs children and regular children may elicit some gaps in the school environment [4]. When regular students and special needs children have significantly different interaction skills at school, special needs children tend to be ignored by their peers. Meanwhile, when regular students can accept special needs children, they will play together at school, maintain cooperation while studying in the classroom, and communicate well with each other. Consequently, special needs children can survive in their social environment with the supportive acceptance of their regular peers [5].

The development of social skills in the wider environment begins at primary school age. School is an important place for children to fulfill their social needs. At school age, children develop their skills through high intensity interaction with their peers [6]. Children also develop a positive attitude to their environment, learn to be adaptive, and build autonomy [7]. In this kind of situation, peer support is important for achieving social tasks successfully during school age years, especially in their "out of home" environment. Parents, friends, and teachers, are the main source of social support for school-age children [8]. When a child enters a school environment, then, peer support becomes one of the most important supports for fulfilling the social development tasks of school-age children [7]. Support from peers in a school environment can help special needs children achieve academic and non-academic success. Peer support in academic life helps special needs children to understand school subjects [9]. Tutors help students with visual impairment during peer tutor learning and provide services to children due to their limitations impeding their understanding of school subjects. In non-academic situations, the role of peer support can enhance the social skills of special needs children, motivate them to learn, increase their confidence, and encourage their acceptance and self-respect. Therefore, peer support is important for achieving social development tasks in all school-age children at primary school [10]. A research study by Solikhatun [11] on hearing impaired people in Semarang shows that they lack confidence due to the lack of social support they receive from their environment. Curtis [12] found that children with slow learning skills needed social support to facilitate the development of independent attitudes and participate in the school community.

One of the factors that affect peer support is social skill. A social skill is a learned skill, composed of a specific behavior that includes how to initiate communication, respond to the social environment, maximize reinforcement from the social environment, and interact with others in the context of a particular situation [13]. There are several studies on the relationship between social skills and social support. Nilsen Karevold, Roysamb and Gustavson found that there is one dimension of relationships derived from social skills, which is communication related to peer social support. Speech delay can disrupt the child's formation of friendships which affects the support gained at school [14]. Good communication skills have a positive effect on the formation of friendships, especially gaining support from friends, meaning children who can communicate well are more accepted by their peers. Hay, Payne and Chadwick explained that social skills are related to peer support, while children who lack good social skills tend to be victims of fraud, bullying, and rejection by peers [15]. However, other research has suggested social skills are not correlated to peer support. Nilsen Karevold, Roysamb and Gustavson [14] found that there was no significant correlation of social skills with peer support. Due to the inconsistency of previous research findings, researchers have searched for other factors that correlate to peer support.

In addition to social skills, the quality of friendship is one of the important factors affecting peer support. Sterret Shire and Kasari [16] proved that there is a relationship between the quality of peer support, social acceptance, and friendship in children with autism. 
A poor quality of friendship causes rejection by peers [17], and loneliness due to not getting support from people [18]; [19]. Previous research has demonstrated a significant correlation between social skills and friendship quality. Therefore, the researchers conducting this study assumed that friendship quality is a mediator of the relationship between social skills and peer support.

A research study conducted by Crawford and Manassis [20] on the respondents aged 8-14 years found that social skills were related to the quality of friendship. Individuals with low social skills also have low quality friendships. Besides, it was found that social skills in children with communication impairments were lacking [21]. Individuals with poor social skill capacities tend to experience problems in their mature relationships. In addition, they tend to experience negative social consequences that will continue as they grow into an adult. These negative consequences can lead to low academic achievement, depression, anxiety, low self-esteem, poor self-concept, withdrawal from the social environment, less opportunities for jobs, and anti-social behavior [22].

Based on the background literature discussed above, the purpose of this research is to investigate the impact of social skills on social support and the mediating effect of friendship quality in special needs children at an inclusive elementary school. High quality friendship is expected to contribute to peer support for special needs children. The main question in this research is "are the impacts of social skills on peer support mediated by special needs children's quality of friendships in inclusive primary schools?" This study consists of theories of each variable, which are social support, social skills and friendship quality. An explanation follows.

\subsection{Social Support}

Social support is a form of support offered by influential people in life and reflected in the immediate environment [23]. The first dimension of social support is emotional support which includes the expression of empathy, concern, and care for the person concerned. Emotional support is an expression of affection, trust, attention, and includes feelings of being listened to. The second dimension is instrumental support, including direct assistance that can be either services, time, or money. The third dimension is informational support which includes advice, tips, suggestions, information or feedback. The last dimension is appraisal support, which includes offering advice and information related to problem solving, that helps to reduce stressors and is used as a means of self-evaluation.

\subsection{Social Skills}

Social skills are a set of behaviors that are demonstrated in various activities within the social environment where behavior is learned. Social skills consist of the following seven elements: (1) communication is a form of behavior where the individual conveys information or messages to the other person verbally or non-verbally, either by expressing opinions or exchanging information; (2) cooperation is a behavior needed to complete a task together with others to achieve a certain goal; (3) assertiveness is an action (behavior) that arises from will and initiative during a social interaction; (4) responsibility is a behavior that involves the exercise of accountability in the social environment; (5) empathy is a behavior that involves identifying, understanding, and being able to feel the feelings of others, and caring for what perceived and experienced by others; (6) participation involves joining an activity undertaken 
by a group/ community; and (7) self-control involves restraint and being able to control emotions in an undesirable situation [24].

\subsection{Friendship Quality}

Friendship quality can be assessed by evaluating positive and negative friendship criteria. Positive characteristics of friendship quality include validation and caring (an aspect that measures the extent to which relationships are characterized by awareness, support, and interest); companionship and recreation (which assesses how much time is spent with friends both within and outside the academic or work environment); help and guidance (assesses how friends try to help each other in the face of routine and challenging tasks); intimate disclosure (how much disclosure of personal information and feelings is involved in a relationship); and conflict resolution (assessing how disputes in relationships are resolved efficiently and well). A negative characteristic of friendship quality is conflict and betrayal (measuring the extent to which relationships are characterized by arguments, disagreements, resentment, and distrust) [5].

\section{METHOD}

\subsection{Respondent}

Respondents were 292 special needs children consisting of 85 (29.2\%) girls and 207 (70.8\%) boys from inclusive primary schools, spread across the fourth to sixth grade. The children's types of disabilities and special needs included emotional disturbances, concentration disorders, intellectual disorders, and physical limitations of mild severity (disability). Authors gave a consent form to all the participants including their parents and guardians in this study to guarantee their privacy. Authors also gave a consent form to teachers as school representatives to obtain their permission and approval for the intake to this study. The severity of the respondents' intellectual impairment was checked by referring to their IQ test results, and based on recommendations from their teachers. Respondents in this research were special needs children able to read and understand a text. Respondents were scattered throughout inclusive primary schools in the Province of DKI Jakarta.

\subsection{The Instrument}

The instrument used to measure social support was the Social Support Questionnaire for Children [23]. Sixteen items measure social support from peers, consisting of four dimensions: emotional support, instrumental support, informational support, and appraisal support. Examples of SSQC's items are my friends cheer me up when I'm sad; my friend bought me food; and my friend approved of my decision. The coefficient reliability of Cronbach's alpha test was 0.832 .

The instrument used to measure friendship quality was the Friendship Quality Questionnaire (FQQ) [5], which had been adapted by Rini Hildayani [25]. Twenty-five items, consisting of six aspects of friendship were used as a reference during the preparation of the measuring instrument, namely validation and caring, conflict and betrayal, companionship and recreation, help and guidance, intimate disclosure, and conflict and resolution. Examples of FQQ items are If someone else is mocking me, then, my friend will defend me; I want to help 
my friend; If I have a problem, I tell my friends etc. The coefficient reliability of Cronbach's alpha test was 0.78 .

The instrument used to measure social skills was the Social Skill Improvement System (SSIS) [24]. The questionnaire consists of twenty-four items based on seven dimensions: communication, self-control, assertiveness, empathy, participation, cooperation, and responsibility. The resulting score illustrates the social skills possessed by respondents. Examples of items of SSIS are When asking for help to others, I say the word "please;" I do what the teacher instructs me to do; I feel bad (uncomfortable) when others are sad. The coefficient reliability of Cronbach's alpha test was 0.834 .

All of the questionnaires used Likert scales with choice of answer A (not true) - D (very true) with an A-D score range of 1-4. Total mean score described the extent of peer support, social skills, and friendship quality among the respondents.

\subsection{Data Analysis}

The data analysis technique used in this research was a regression of multiple regressions with the Hayes mediation test of the research model. This technique was used to determine the relationship between social skills and peer support mediated by friendship quality. The statistical calculation used the Statistical Program for Social Sciences (SPSS) version 23.0 for windows. The following picture depicts the research model used in this study:

Figure 1: The research model Based on Hayes Model

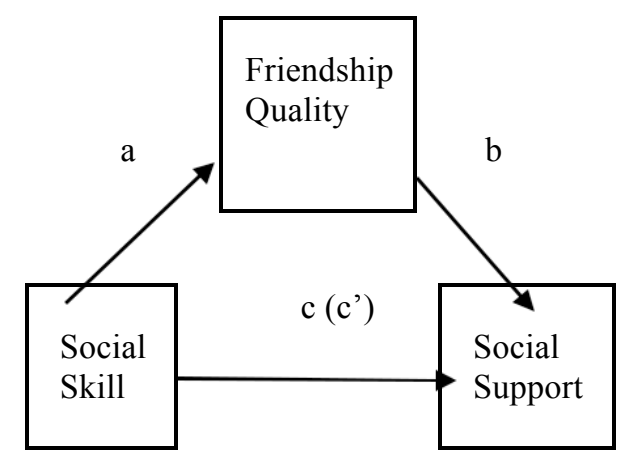

\section{RESULTS}

The researchers investigated relationships between three variables, namely the quality of friendship, social skills, and peer support. The following description explains the results of statistical tests conducted by the researchers related to the mean and standard deviation values for each variable.

In this study, a description of the quality of friendships, social skills, and peer support were obtained by using midpoint values on a scale measuring the quality of friendship. The midpoint value is the middle value of the scale range used by the measuring instrument. The quality of friendship (FQQ), social skills (SSIS), and peer support (SSQC) are measured by using a scale of $1-4$, where the midpoint value is 2.5 . Based on this value, if the mean value is 
$<2.5$, then the respondent has low quality friendships, social skills, and peer support. If the mean value obtained by the respondent is $>2.5$, then, the respondent has high quality friendships, social skills, and peer support.

Table 1 describes the quality of special needs children's friendships in inclusive primary schools:

Table 1. Description of friendship quality for special needs children $(\mathrm{N}=292)$

\begin{tabular}{lllll}
\hline $\begin{array}{l}\text { Dimension of } \\
\text { Friendship } \\
\text { Quality }\end{array}$ & $M$ & $S D$ & $\begin{array}{l}\text { Minimum } \\
\text { Score }\end{array}$ & $\begin{array}{l}\text { Maximum } \\
\text { Score }\end{array}$ \\
\hline $\begin{array}{l}\text { Validation } \\
\text { and caring }\end{array}$ & 2.62 & 0.45 & 1.00 & 4.00 \\
$\begin{array}{l}\text { Conflict } \\
\text { resolution }\end{array}$ & 2.68 & 9.61 & 1.00 & 4.00 \\
$\begin{array}{l}\text { Conflict and } \\
\text { betrayal }\end{array}$ & 3.03 & 0.61 & 1.00 & 4.00 \\
$\begin{array}{l}\text { Help and } \\
\text { guidance }\end{array}$ & 2.74 & 0.57 & 1.00 & 4.00 \\
$\begin{array}{l}\text { Companion- } \\
\text { ship and } \\
\text { recreation }\end{array}$ & 2.73 & 0.51 & 1.00 & 4.00 \\
$\begin{array}{l}\text { Intimate } \\
\text { disclosure }\end{array}$ & 2.26 & 0.69 & 1.00 & 4.00 \\
\hline
\end{tabular}

The results in Table 1 on the six dimensions of friendship quality reveal that the highest mean value is in the conflict and betrayal dimension at 3.03. This dimension has a high category because the mean value is already $>2.5$, followed by other dimensions; validation and caring, conflict and resolution, help and guidance, companionship and recreation. Meanwhile the dimension of intimate exchange has the lowest average $<2.5$ and is the lowest category. Thus, it can be concluded that the quality of special needs children's friendships in inclusive primary schools in Jakarta is high, because all of the dimension of friendship quality have a high mean value, except in the dimension of intimate exchange. 
Table 2 lists the result of calculating the mean and standard deviation for each dimension of social skills:

Table 2. Description of social skills in special needs children $(\mathrm{N}=292)$

\begin{tabular}{lllll}
\hline $\begin{array}{l}\text { Dimension of } \\
\text { Social Skill }\end{array}$ & $M$ & $S D$ & $\begin{array}{l}\text { Minim- } \\
\text { um } \\
\text { Score }\end{array}$ & $\begin{array}{l}\text { Maximum } \\
\text { Score }\end{array}$ \\
\hline Empathy & 2.59 & 0.55 & 1.00 & 4.00 \\
Cooperation & 2.97 & 0.46 & 1.00 & 4.00 \\
Self-control & 2.20 & 0.79 & 1.00 & 4.00 \\
Communication & 2.89 & 0.48 & 1.00 & 4.00 \\
$\begin{array}{l}\text { Assertion } \\
\text { Responsibilit }\end{array}$ & 2.94 & 0.54 & 1.00 & 4.00 \\
y & 2.72 & 0.52 & 1.00 & 4.00 \\
Participation & 2.87 & 0.53 & 1.00 & 4.00 \\
\hline
\end{tabular}

Based on the results from Table 2 above, the mean and standard deviations of social skills in special needs children at inclusive primary schools have varying values. The smallest average value and standard deviation was in the dimension of self-control, that is $\mathrm{M}=2.20$. Based on these values, it can be said that special needs children in inclusive schools have low self-control, whereas in other dimensions, such as empathy, cooperation, communication, assertion, and participation, they had higher social skills. Thus, it can be concluded that special needs children in inclusive primary schools have relatively high levels of social skills in most dimensions.

Table 3 displays the results of calculating the mean and standard deviations of each dimension of peer support.

Table 3. Description of peer support for special needs children $(\mathrm{N}=292)$

\begin{tabular}{lllll}
\hline $\begin{array}{l}\text { Dimension of } \\
\text { Peer Support }\end{array}$ & $M$ & $S D$ & $\begin{array}{l}\text { Minim } \\
\text {-um } \\
\text { Score }\end{array}$ & $\begin{array}{l}\text { Maximum } \\
\text { Score }\end{array}$ \\
\hline $\begin{array}{l}\text { Emotional } \\
\text { support }\end{array}$ & 2.68 & 0.48 & 1.00 & 4.00 \\
$\begin{array}{l}\text { Instrumental } \\
\text { support }\end{array}$ & 2.63 & 0.51 & 1.00 & 4.00 \\
$\begin{array}{l}\text { Information- } \\
\text { al support }\end{array}$ & 2.61 & 0.55 & 1.00 & 4.00 \\
$\begin{array}{l}\text { Appraisal } \\
\text { support }\end{array}$ & 2.56 & 0.58 & 1.00 & 4.00 \\
\hline
\end{tabular}


Based on the results outlined in Table 3 assessing the peer support of special needs children in inclusive primary school, all dimensions of peer support are high categories, where each has a value $>2.5$. Thus, special needs children in inclusive primary schools receive high levels of social support from their peers. In conclusion, special need children in inclusive primary schools in Jakarta enjoy a high quality of friendship, social skills, and peer support.

The first stage of testing the research model analyzed correlations between variables, as shown in Table 4.

Table 4. Score of correlation between research variables

12

1. Social skill

2. Friendship $0.654 * *$

quality

3. Peer support $\quad 0.443 * * \quad 0.655^{* *}$

**Significant correlation in 0,01 (2-tailed)

These results revealed a significant correlation between social skills and social support with $\mathrm{p}<0.01$. Second, there was a significant correlation between social skills and friendship quality with $\mathrm{p}<0.01$. Third, there was a significant correlation between social skills and friendship quality and social support with $\mathrm{p}<0.01$. This indicates that friendship quality fully mediates the effect of social skills on social support. This following information displays the results of the regression analysis.

Table 5. Results of the regression analysis of research variables

\begin{tabular}{cccccccc}
\hline Variables & $\begin{array}{c}\text { Unstandar- } \\
\text { dized } \\
\text { Coefficient } \\
\text { S }\end{array}$ & $\begin{array}{c}\text { Stan } \\
\text { dar- }\end{array}$ & & & \\
dize \\
\end{tabular}


Notes: IV:Independet Variable; DV: Dependent Variable; B1; Beta; SS1: Social Skill; SS2: Social Support; FQ: Friendship Quality

Based on Table 5, it can be concluded that social skills affect social support due to the mediating effect of the quality of friendship. Social skills contribute to the quality of friendship by $42.8 \%\left(\mathrm{R}^{2}=0.428\right)$. It is greater than the contribution to social support, that is $19.6 \%\left(\mathrm{R}^{2}=0.196\right)$. This reveals that social skills significantly influence friendship quality $(\mathrm{t}$ $=14.733 ; \mathrm{p}<0.05)$. In this research, social skills and friendship quality contribute by $43 \%\left(\mathrm{R}^{2}\right.$ $=0,430)$ to social support. Based on the positive and significant relationship between friendship quality and social support, it can be demonstrated that the higher their social skills, the higher the social support obtained by special needs children. The following figure depicts the results of the research without the mediator:

Figure 1: Corellation Social Skill to Peer Support

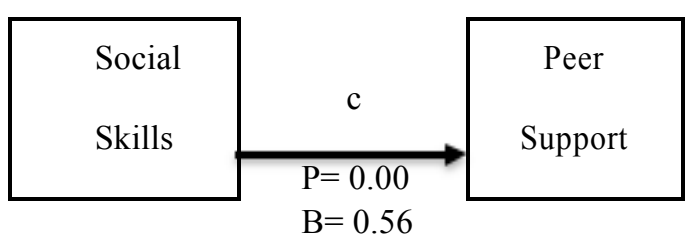

Based on Figure 1 above, it can be seen that the value of B or coefficient of social skill on the quality of friendship is 0.56 with a significance value of 0.00 . This means that social skills significantly influence the quality of friendships in special needs children in inclusive primary schools. After testing the research model without using the mediator, the researchers tested the research model using the mediator. The results were as follows:

Figure 2: Mediation Model Research

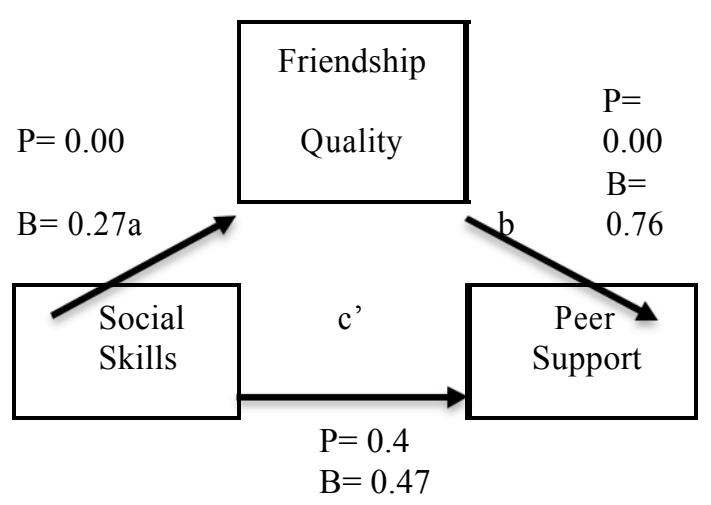

The model analysis of the ability of social skills to predict social support due to mediation by the quality of friendship shows that although social skills affect the social 
support obtained, social skills are not a good predictor of social support when friendship quality plays a role in the relationship. The value coefficient (B) between social skill and friendship quality, and friendship quality and social support, demonstrates that both of them are positive. Therefore, it can be concluded that friendship quality is a good mediator of the impact of social skills upon social support. Higher value social skills increase peer support values in line with the quality of friendship.

Researchers conducted a regression analysis with the Hayes test to determine the role of any mediating influence on each variable. Figure 2 demonstrates the significant value of the total effect is smaller than the direct effect. This means the influence of social skills on social support is a fully mediated by the quality of friendship. Full mediation in this research means there was no correlation between social skills and social support without mediation by friendship quality.

\section{DISCUSSION}

Based on these results, we can see that there a significant correlation between social skills and social support was revealed (without any mediator). This result supports a previous study by Hay, Payne and Chadwick [15] which explained that social skills had a strong relationship to peer support; meaning that children who lack social skills tend to be victims of fraud, bullying, and rejection by peers. In our study, special needs children with good social skills obtained good social support especially from their peers.

After that, we checked for correlations with the mediator, and the c value (social skills on peer support) became insignificant when friendship quality was a mediator. This shows that friendship quality fully mediated the relationship between social skills and peer support. The role of friendship quality in obtaining social support was also found in previous research by Sebanc [17] which demonstrated that a poor quality of friendship caused rejection by peers [17]. This result supports the research by Nangle, Erdley, Newman, Mason and Carpenter [18]; Lodder et, al [19], which describes loneliness as a consequence of a lack of support from people in the immediate environment. It also supports Papalia's [7] study results, which indicated that peers become the main source of support after forming a friendship. Therefore, good quality friendships are positively correlated with good social support for special needs children. This means that friendship quality has an important role in developing peer support for special needs children.

In addition, social skills contribute far more to friendship quality than they contribute to social support. When friendship quality mediates the relationship between social skills and social support, then the value both variables becomes much larger. This is in line with the theory expressed by Crawford and Manassis [20] which investigated the impact of social skills on the quality of friendship in respondents aged 8-14 years. They found that social skills had a relationship with the quality of friendship. In brief, individuals with poor social skills tend to have poor quality friendships. This proves that social skills have a strong bearing on friendship quality. In addition, friendship quality deepens relationships and the influence of peer support on special needs children when friendship quality mediates peer support along with social skills.

The mean and standard deviation scores of all the variables in this study were relatively high. Previous studies have stated that special needs children have poor social skill scores [15], poor social support [11], and poor quality friendships [26]. The mean scores for social skills were high in all five dimensions in this study. These were empathy, cooperation, 
communication, assertiveness, and participation. This means that special needs children in this study were able to develop these dimensions of social skills at an inclusive school, for example; smiling and laughing with friends and cooperation in groups when finishing some task. However, one dimension with low social skills score was the dimension of self-control. Many of the respondents had emotional and behavioral disorders. Their special needs led them to experience low self-control when situations did not meet their expectations [26]. They had high quality friendship scores because they had high social skills scores, which in turn affected the development of friendship quality at school. Furthermore, special needs children at inclusive schools also experience good social support especially from their peers, due to their high quality friendships and good social skills.

This study was limited due to the authors' poor access to people who understand special needs children sufficiently to help during the data collection process. Every child needed to be accompanied by one adult to complete the questionnaire. When the authors collected data, they were accompanying five special needs children at a time; therefore, it took a long time to complete the data collection. In future research, a research assistant should be prepared by the researchers to help collect the data.

The researchers suggest optimizing peer support by facilitating the development of social skills and quality friendships among special need children. Schools can create (small) learning groups to support academic goals, and play groups to support non-academic goals that include special needs children together with regular students. In such groups, regular students could act as companions for special needs children.

Friendship quality is a good predictor of peer social support for special needs children in inclusive elementary schools, aside from social skills. Good social skills and high quality friendships in special needs children will establish high levels of social support from peers, which helps children to successfully fulfill social development tasks during school age, and builds the social capital needed to help children survive and thrive socially in the future.

\section{REFERENCES}

[1] Mangunsong, F. 2014. Psikologi dan pendidikan anak berkebutuhan khusus. Jilid kesatu. Depok: LPSP3 UI.

[2] The Ministry of Education. 2017. Sekolah inklusi dan SLB dukung pendidikan inklusi. https://www.kemdikbud.go.id/main/blog/2017/ 02/sekolah-inklusi-dan-pembangunanslb-dukung-pendidikan-inklusi> [Accessed 3 January 2017].

[3] Raschke, D. and Bronson J. 1999. Creative Educators at Work: All Children Including Those with Disabilities Can Play Traditional Classroom Games. $<$ www.uni.e.,du/coe/inclusion/preparing/> [Accesed 12 December 2017]

[4] Woolfolk, A. 2009. Educational Psychology. Jogjakarta: Pustaka Pelajar.

[5] Parker, J. and Asher, R. 1993. Friendship and friendship quality in middle childhood: links with peer group acceptance and feelings of loneliness and social dissatisfaction. Journal of Developmental Psychology, 4, 611-621.

[6] Hurlock, E. B. 1980. Psikologi perkembangan suatu pendekatan sepanjang rentang kehidupan (Edisi kelima). Jakarta: Erlangga.

[7] Papalia, E. D., Sally, W. O. and Ruth, D. F. 2009. Perkembangan manusia. Edisi kesepuluh. Jakarta: Salemba Humanika.

[8] Elliott, S.N., Malecki, C.K., \& Demaray, M.K. (2001). New directions in social skills assessment and intervention for elementary and middle school students. Exceptionality, 9(1-2), 19-32. 
[9] Selvi., Iswari, M. and Ardisal. 2013. Peranan tutor sebaya dalam membantu proses pembelajaran bagi siswa tunarungu di SMP 23 Padang. Jurnal Ilmiah Pendididkan Khusus, 2, 727-735.

[10] Foster, K. 2011. Using a peer buddy system to increase interaction between students with special needs and their peers. Theses and Dissertations: 257. $<\mathrm{http}: / /$ rdw.rowan.edu/etd/257> [Accessed 3 June 2017]

[11] Solikhatun, Y. U. 2013. Penyesuaian sosial pada penyandang tunarungu di SLB Negeri Semarang. Educational Psychology Journal. $<$ http://journal.unnes.ac.id/sju/index.php/epj> [Accessed 4 March 2017]

[12] Curtis, C. K. 2015. Social studies the slow learner. Journal of Educational Strategies, Issues and Ideas, 48, 456- 460.

[13] Hupp, S. D. A., Le Blanc, M., Jewell, J. D. and Warnes, E. 2009. History and overview. In Johnny L. Matson. Social Behavior and Skills in Children. Los Angeles: Springer.

[14] Nilsen, W., Karevold, E., Roysamb, E. and Gustavson, K. 2013. Social skills and depressive symptoms across adolescence: Social support as mediator in girls versus boys. Journal of Adolescence, 36, 11-20.

[15] Hay, D. F., Payne, A. and Chadwick, A. 2004. Peer relations in childhood. Journal of Child Psychology and Psychiatry, 45, 84-108.

[16] Sterrett, K., Shire, S. and Kasari, C. 2017. Chapter two: Peer relationsips among children with ASD: Interventions targeting social acceptance, friendship, and peer networks. International Review of Research in Developmental Disabilities, 52, 37-74.

[17] Sebanc, A. M. 2003. The friendship features of preschool children: Links with prosocial behavior and aggression. Social Development, 12, 249-268.

[18] Nangle, D. W., Erdley, C. A., Newman, J. E., Mason, C. and Carpenter, E. M. (2003). Popularity, friendship quantity, and friendship quality: Interactive influences on children's loneliness and depression. Journal of Clinical Child \& Adolescent Psychology, 32, 546-555.

[19] Lodder, G. M. A., Scholte, R. H. J., Goossens, L., \& Verhagen, M. (2015). Loneliness in early adolescence: Friendship quantity, friendship quality, and dyadic processes. Journal of Clinical Child and Adolescent Psychology.

[20] Crawford, M. and Manassis, K. 2011. Anxiety, social skills, friendship quality, and peer victimization: An integrated model. Journal of Anxiety Disorder, 25, 924-931.

[21] Johnson, H., Douglas, J., Bigby, C. and Iacono, T. 2010. The pearl in the middle: A case study of social interactions in an individual with severe intellectual disability. Journal of Intellectual \& Developmental Disability, 35, 175-186.

[22] Lee, S. W. (2005). Encyclopedia of school psychology. Thousand Oaks: SAGE Publications, Inc.

[23] Harter, S. 1985. Social Support Scale for Children: Manual and Questionaires. Colorado: University of Denver.

[24] Gresham, F. M. and Elliott, S. N. 2008. Social skills improvement system: Rating scales manual. Minneapolis, MN: Pearson Assessments.

[25] Hildayani, R. 1997. Pertemanan lawan jenis pada dewasa muda pria dan wanita yang telah menikah. Universitas Indonesia.

[26] Hallahan, D. P., \& Kauffman, J. M. (2006). Exceptional learnears: Introduction to special education. $\left(10^{\text {th }}\right.$ ed.). Boston: Allyn and Bacon. 
